\title{
Postmodernism and the Reclaiming of Tradition
}

\author{
Laurence Piper
}

\section{Introduction}

'The history of the Zulu people is the history of myself'. ${ }^{1}$ In Africa, as elsewhere, the notion of tradition is bound up with the discourses of ethnicity and nationalism. Typically invoking pre-colonial identities as the basis of peoplehood, such narratives of common descent are imbued with a strong sense of 'pastness', orientating the modern self in traditional terms. Anderson explains this invocation of tradition as a feature of the inverted nature of ethnic narratives of common descent. ${ }^{2}$ More common are accounts which focus on the 'loss of meaning' brought about by modernisation and the psychic security offered by an idealised past. Recent theories look to supplant this sense of tradition as reaction with a sense of tradition as creation. One example is Lonsdale's argument that the affirmation of ethnicity in post-colonial Africa, with its associated invention of tradition, must be seen in the context of internal debates over civic virtue as pre-colonial moral economies are re-structured by the state and capitalism. ${ }^{3}$

If, for whatever reason, the appeal to tradition is central to ethnic and nationalist discourses in Africa, it is an appeal set in opposition to 'the modern'. A legacy of late-nineteenth century European colonial discourse, 'civilisation' with its Christian moral being and 'enlightening' education, was contrasted with a 'primitive', 'barbaric' and 'warlike' tribal other. Ironically reproduced by the assimilationist African élite, strands of this opposition continue to flavour political discourse to this day. In fact, the mediation of this tension between the modern and the traditional, the European and African, the future and the past has formed a central theme in African identity politics this century. ${ }^{4}$ A contemporary example is KwaZulu-Natal MEC for Traditional Affairs Inkosi Nyanga Ngubane's recent defence of the local authority of amakosi (chiefs) (Natal Witness 22/10/94).

Long a target of enlightenment rationalism, tradition was cast as an apologist for arbitrary and oppressive authority. Further, as the modern world has become increasingly organised along rationalist 
lines, 'magic and mystery' have been lost: as Weber puts it, the modern world is a 'dis-enchanted' one. If so, this suggests that tradition, and perhaps with it ethnicity, is ultimately doomed. Recent developments in social theory call this assumption into question, however. The rise of 'postmodern' theories concerned with a 'postmodern condition' criticise reason rather than tradition. Reason has been exposed as unavoidably entangled in history, society, power, practice and interest, body and desire; its claims to be the sole legitimate source of truth and author of action have been revealed as artificial, and its victims in the 'war for liberation' have been unfairly subordinated, repressed and dominated. Further, as Zygmunt Bauman puts it, postmodernism is concerned to 're-enchant' the world modernity tried to 'dis-enchant' (1992:x). Will tradition be re-affirmed in this return of the repressed?

In answering this question, this paper (i) recounts the original defence of tradition by the English traditionalists Burke and Oakeshott. This defence is then considered in relation to (ii) the philosophical treatment of tradition offered by Gadamer, and (iii) the sociological approach of Giddens. On this basis it is argued that tradition remains a legitimate, if weakened, source of authority in an increasingly 'post-traditional' world. This ambiguous re-claiming leaves ethnic and nationalist discourses awkwardly - sometimes ominously - poised.

\section{I}

Our reason must be considered as a kind of cause, of which truth is the natural effect ...

David Hume

[Tradition] appears to me to be the result of profound reflection; or rather the happy effect of following nature, which is wisdom without reflection, and above it.

Edmund Burke

In 1793 Marie-Jean-Antoine-Nicolas Caritat, Marquis de Condorcet, under threat of death by the Jacobins, went into hiding to write his Esquisse d'un tableau historique des progres de l'esprit humain. Published posthumously in 1795, the Esquisse was hailed as a testament of the French Enlightenment and was adopted as the philosophical 
manifesto of the post-Thermidorian reconstruction. In less than two hundred pages Condorcet covers nine epochs of human history, culminating with a euphoric description of the tenth epoch: 'The Future Progress of the Human Mind'. Progress for Condorcet does not simply mean development, but progress towards the perfection of the human species. The hero of his narrative is Reason which, triumphing over the devious tactics of priests, tyrants, despots and cunning hypocrites, gains an overwhelming momentum. The endpoint of the logic of Reason is nothing other than the full realisation of justice, virtue, freedom, and happiness for the human race, the liberation of humankind from arbitrary power, superstition and tradition.

Although perhaps the zenith of Enlightenment hyperbole, Condorcet's testament is clearly rooted in a Rationalist discourse that stretches from Descartes to modern times; a discourse that, although diverse, shares a common rejection of tradition as the source of truth about the world, reserving this role for reason alone. As early as 1637, one hundred and fifty years before Condorcet's Esquisse, Rene Descartes had drawn this opposition. Observing in the Discourse on Method that 'the ground of our opinion is far more custom and example than any certain knowledge', and that 'absurd and incredible' beliefs were widely received by 'common consent', he resolved 'never to allow ourselves to be persuaded of the truth of anything unless on the evidence of our reason'. This antinomy between the misrepresentations of 'custom and example', the 'truths' of tradition, and the genuine enlightenment provided by individualist reason, echoes the description of the 'modern rationalist' that Michael Oakeshott offers 300 years later:

At bottom he [the modern rationalist] stands (he always stands) for independence of mind on all occasions, for thought free from obligation to any authority save the authority of 'reason'. His circumstances in the modern world have made him contentious: he is the enemy of authority, of prejudice, of the merely traditional, customary or habitual. His mental attitude is at once skeptical and optimistic: skeptical, because there is no opinion, no habit, no belief, nothing so firmly rooted or so widely held that he hesitates to question it and to judge it by what he calls his 'reason'; optimistic because the Rationalist never doubts the power of his 'reason' (when properly applied) to determine the worth of a thing, the truth of an opinion or the propriety of an action. (Oakeshott 1962:1-2)

The rationalist attack did not go undefended. The French Revolution prompted a furious debate between Condorcet and company on 
the one hand, and defenders of tradition such as Edmund Burke, on the other. Burke argued that tradition embodied the practical experience of generations, moral, spiritual and political which mirrored the workings of nature. Reason had a role, but only in a framework of ends and means derived from tradition (and therefore from the aristocracy). The doctrine of the 'revolutionary society' is, Burke claims, a 'barbarous philosophy, which is the offspring of cold hearts and muddy understanding ... void of all solid wisdom, as it is destitute of all taste and elegance' (Butler 1984:45). Despite his caveat on the role of reason, Burke repeats the Enlightenment opposition between tradition and reason as mutually exclusive paths to truth. That noted, he does identify the two key concerns of traditionalists: the demise of practical knowledge and the relationship between tradition and authority. These issues are central to Oakeshott's more sophisticated defence of tradition nearly two centuries later.

Oakeshott argues that rationalism has appropriated reason in a onesided manner. Enamoured with reason and method, rationalism mistakes technical knowledge for knowledge as a whole. What this misconception misses, he argues, is practical knowledge - that element of truth which is 'imparted and acquired'; can be learnt only by 'apprenticeship to the master'; that knowledge which, accumulated over generations, becomes encoded in tradition. Following Pascal, Oakeshott argues that this philosophical mistake is mirrored at the level of practical action by the belief that certain knowledge contains more truth than probable knowledge. This belief rests on an exaggerated conception of the importance of rational method or technical proficiency, thus limiting the insight of reason. The practical advantage of tradition, Oakeshott insists, is that it contains more of the whole truth than the partiality of rational method can ascertain. What is required, he concludes, is the mutual co-existence of reason and tradition in such a manner that the limits of technical reason are acknowledged, and hence the claims of authority recognised. Thus while echoing Burke's concern with the demise of practical reason, Oakeshott attempts to avoid the polarisation of reason and tradition as mutually exclusive paths to truth.

The outcome of the confrontation between the rationalists and traditionalists is well known. Weber saw 'occidental' rationalism 'disenchanting' Europe of religious world-views, ushering in a secular culture, and permeating and defining the operation of key institutions (Habermas 1985:1). However more recent developments suggest that the victory of reason over tradition must be re-evaluated. Central here 
is the widespread sense of social change as the twentieth century draws to a close - a condition often termed 'postmodern'. Richard Bernstein characterises this Stimmung ${ }^{5}$ as one which affirms incommensurability, otherness, alterity, difference and plurality against the claims of a universal, totalising reason. In fact, much of twentieth century philosophy is concerned with debunking the enlightenment legacy's account of reason, a tendency Bernstein labels the 'rage against reason'. There are two aspects to this. On the one hand, the twentieth century has witnessed the dark side of the promise of reason: totalitarianism, genocide, death-camps, the threat of nuclear holocaust and environmental destruction. On the other, there has been a corresponding discontentment with established political and philosophical discourses. As Thomas McCarthy puts it:

The overwhelming 'impurity' of reason, its unavoidable entanglement in history and tradition, society and power, practice and interest, body and desire, has prompted, amongst others, Nietzsche's heroic proclamation of the end of philosophy, Wittgenstein's therapeutic farewell, and Heidegger's dramatic overcoming. (in Habermas 1985:vii)

In the light of the problematisation of Enlightenment reason, the defence of tradition as represented by Burke and Oakeshott deserves reappraisal. Whilst the force of their arguments is a matter of some dispute, the debate might be clarified by engaging with more recent attempts at rehabilitating tradition, notably the work of Hans-Georg Gadamer and Anthony Giddens.

\section{II}

Long before we understand ourselves through the process of selfexamination, we understand ourselves in a self-evident way in the family, society and state in which we live. The focus of subjectivity is a distorting mirror. The self-awareness of the individual is only a flicker in the closed circuits of historical life.

Hans-Georg Gadamer

Gadamer's work has an intimate relationship with the current emphasis on the limits of philosophy and with the question of tradition. In Truth and Method, Gadamer develops a philosophical account of hermeneutical understanding which criticises the Enlightenment belief in scientific method as the sole way to 'objective' truth. Central 
to this critique is the rehabilitation of 'prejudice' and tradition, as well as an emphasis on the importance of phronesis to the process of understanding. As well as sharing these Oakeshottian themes, Gadamer appears, at times, to echo the widespread 'traditionalist' commitment to authority. ${ }^{6}$ There are, however, crucial differences between Gadamer and even the most sophisticated 'traditionalist' views. These differences exist both at the philosophical level in Gadamer's account of the nature of truth-claims, as well as the political level in the relationship between tradition and authority. The upshot of these differences is that Gadamer comes to articulate an understanding of tradition markedly different from the traditionalist versions.

Philosophically, Gadamer's account emerges from a critique of positivism which emphasises the necessary role of prejudice and authority in the process of truth-redemption. There are three steps to this claim: First is Gadamer's adaptation of Husserl's claim that the understanding of an object is the understanding of that object as something. This means all understanding involves projecting meaning in perceiving that is not strictly contained in the perceptions themselves. Such projection is not subsequent to the experience of senseperception but immediate and intuitive. This phenomenological point means that the content of a perception is always 'prejudiced' as it necessarily involves a point of view of some sort. Gadamer's draws on the conception of the hermeneutic circle in developing an understanding of the nature of such 'prejudice'. Dilthey, for example, argued that understanding a text always involved a projection of its meaning on the basis of a partial experience of it. Of course such a projection might well be re-evaluated in the light of subsequent reading. Thus Gadamer argues against the enlightenment that prejudice here literally means 'prejudgement' - something that is temporary, and can be confirmed or denied by further reading. To assume that all prejudices are misleading, as the Enlightenment does, is simply a 'prejudice against prejudices'.

Second, Gadamer draws on Heidegger in arguing that all interpretive projections of meaning are rooted in the situation of the interpreter. Heidegger terms this situated determination of meaning the fore-structure of understanding. More precisely this means that before one has begun to consciously interpret a text, one has already placed it in a certain context (Vorhabe), approached it from a certain perspective (Vorsicht), and conceived of it in a certain way (Vorgriff). 
The meaning of any object then is 'co-determined' by one's own life circumstances, or 'life-relations', by one's 'thrownness' in Dasein.

Third, whilst Heidegger locates understanding in the concerns of the interpreting subject, Gadamer emphasises the historical dimension of this structure of involvements. This means that the issues that one brings to the process of interpretation are not one's preoccupations alone, but refer to the issues and concerns within the historical tradition to which one belongs. Thus the situation of 'thrownness' is not itself unconditioned or arbitrary, but rather stems from the tradition in which we are rooted. Consequently, even the shock quality of contemporary art is orientated by the tradition from which it deviates. This means that a statement about the meaning of a work of art is not an individual statement, but rather one that reflects one's inheritance. At work here is what Gadamer terms 'effective history', the 'operative force' of tradition over those who belong to it.

Thus against the Enlightenment Gadamer argues that our idea of reason is itself grounded in a tradition and, in this sense, the opposition of reason and tradition makes no sense. Rather, understanding involves either immediate insight into the 'truth-claim' advanced (an understanding of die Sache), or an act of interpretation which reveals the 'truth-claim' of the object apparent. Understanding reached through interpretation is hermeneutical, and involves what Gadamer terms the 'fusion of horizons', where the 'truth-claim' of the 'other', situated in a horizon of historical meanings, meshes with the horizon of meanings of the interpreter. This involves a process of reasoned dialogue in an attitude of mutual openness so as to come to agreement and hence an understanding about a truth-claim.

Whilst concurring with the traditionalists that reason is not the sole method to truth, Gadamer differs clearly from Burke's claim that reason has no fundamental role in truth-redemption. In describing the hermeneutic process as a 'dialogue' in which one is open to the 'otherness of the other', reason clearly has a role. This appears to move Gadamer closer to Oakeshott's claim that practical reason, or phronesis, transmitted through tradition, is what is required for truthredemption. Indeed, Oakeshott favourably quotes Pascal's argument that rationalism rests on a false criterion of certainty, whereas practical knowledge, moving from a basis of probability rather than certainty, 'has more of the whole truth than certain knowledge'. However, it seems to me that Gadamer understands the nature of phronesis not so much as actual truth-claims verified by experience and encoded in a tradition, but rather as the skilful handling of the process 
of attaining such truth-claims out of the mediation of the horizons of meaning of partners in dialogue.

This argument rests on Gadamer's conception of the process of truth-redemption, which follows three steps. First, is the assumption in favour of the truth-claim of one's partner in dialogue. This assumption is made so as to prevent the truth-claim which emerges from the hermeneutic process simply being the function of one's own prejudices. By assuming the truth of claims made by one's partner in dialogue, and so opening one's prejudices to reflection and doubt, the emergent claim cannot simply be 'subjectivist'. This argument draws on Dilthey's and Schleiermacher's accounts of the hermeneutic circle, but the guiding assumption is not one of coherence, but one in favour of the truth-claim of a text. Thus if an interpretation of a text along the lines of the hermeneutic circle makes the text take a position that appears obviously false, this indicates the possible inadequacy of the interpretation. What is required is an openness to the otherness or the distinctness of the text, a privileging of the text as having a certain normative authority.

However, this caveat of openness seems merely to replace one's initial assumptions with the claims made by one's partner in dialogue. Is one not simply replacing certain unexamined prejudices with other views explicitly taken from tradition? At this point Gadamer introduces his second point: the 'applicative moment'. The views of tradition are never simply adopted, he holds, but modified in relation to one's concerns and historical circumstance. Quoting Aristotle's criticism of Plato's account of ethical knowledge, Gadamer argues that meaning is only realisable when related to particular concrete circumstances. Like ethical knowledge, he argues, the demands of the particular are the grounds of possible meaning. Our particular concerns and prejudices shape the line of questioning in the hermeneutic process, and hence the answers (and meaning) that are given. This argument appears to answer the charge that hermeneutic understanding seems to involve an acquiescence to the authority of tradition. We do not simply adopt the view of tradition; rather, the way we understand its truth already involves application to our situation. Thus against Oakeshott, Gadamer sees phronesis as the procedural skill of mediating the universal with the particular, as opposed to established fore-knowledge of the particular.

There is however, a crucial ambivalence in how Gadamer articulates the significance of the 'understanding' reached in the hermeneutic process. In more conservative moments, Gadamer appears to take 
'understanding' as the 'fusion of horizons' where the truth-claim of object and interpreter are necessarily intertwined into a new, different truth-claim. This more Hegelian moment has the consequence of always orientating the interpreter to attaching an ongoing normative status to tradition, rather than a temporary one. But as Warnke argues, why should one always orientate oneself to coming to an agreement with tradition? Why should we not define our opinions in opposition to tradition? Consider the case of interpreting Mein Kampf for example. Rather, following Warnke, it seem appropriate to read Gadamer's 'fusion of horizons' as involving coming to an agreement about the meaning of a truth-claim, rather than accepting the claim as valid for oneself (Warnke 1987:134-138).

This conclusion is important as it distances Gadamer's account from traditionalist defences of authority. This is most importantly expressed in the meaning ultimately ascribed to the notion of tradition: no longer a privileged access to truth, it becomes more the social origin of our prejudices; the discourses, social practices, symbolic order in which we are located; the particularity which constitutes us; the baggage we inherit. While retaining a sense of tradition as from the past, this reading of Gadamer breaks the link between tradition and authority by undermining the claim of tradition to any special access to truth. Thus Gadamer does not so much bolster tradition in its engagement with reason as undermine the epistemological opposition between the two. Or to put it another way, he joins the postmodern refrain concerning the limits of possible knowledge.

\section{III}

A post-traditional order is not one in which tradition disappears - far from it. It is one in which tradition changes its status. Traditions have to explain themselves, to become open to interrogation or discourse.

Anthony Giddens

If this reading of Gadamer is right, if neither tradition nor reason is epistemologically privileged, what does this mean for a world in which the opposition between reason and tradition seems very much alive? For anthropologists and sociologists the answer to this question depends on whether one embraces a 'weak' or 'strong' reading of tradition. The former refers to a broader sense of tradition as a 'longestablished' social practice therefore assigned normative value, the latter to a narrower sense of tradition as involving a specific form of 
validation: ritual assertion by authority figures. Thus, whereas for the former the opposition between reason and tradition is misleading as all societies have their own long-established social practices, for the latter tradition is associated with a historically specific form of institutional authority. On this view then, the traditional nature of a society is open to empirical investigation. Importantly, although Gadamer appears to have advanced the weaker sense of tradition, his account is equally compatible with either view as his concern was epistemological not sociological.

An example of a 'weak' traditionalist is Edward Shils. Shils argues that contemporary society retains a traditional aspect in that the successful institutionalisation of reason relies on it becoming traditional, that is, being accepted because it is 'handed down from the past'. This argument covers several key points: 'traditionality', as he terms it, is not associated with any one substantive content. Further, although it is 'handed down from the past' there is nothing which stipulates how long it must be handed down - although he decides three generations is a good rule of thumb. It can also be handed down in any form, oral or written. Nevertheless, tradition is more than the statistically frequent recurrence over generations of similar beliefs, practices and so on, in that this recurrence is a consequence of the acceptance of the tradition as 'normative'. It is this normative transmission which is the 'inertial force' which holds society in a given form over time. Thus the distinctive feature of tradition is that its truth claims are believed because they 'were believed previously', and thus deserving of 'faith'. It would be mistaken to term contemporary society 'post-traditional', Shils holds, because traditional justification is an integral part of the glue which holds together all societies.

In contrast with Shils, Pascal Boyer argues that it is possible to distinguish traditional from modern societies on the basis of the 'traditional' status of key institutions. From an examination of oral traditional practices in 'pre-modern' societies, Boyer argues that tradition has less to do with cosmological beliefs than the redemption of causal truth-claims about a state of affairs. The criteria for accepting such claims depend both on who makes such claims (only certain people are seen as truthful) and the correct rituals for making such claims. For Boyer, traditional practices are thus forms of communication which rely on belief in the authority of particular persons and social practices. Whether one can term a society 'traditional' depends on the extent of tradition practices to be found in a society. Thus, he notes, while all societies seem to have some form of traditional behaviour 
(he cites Luhrmann's monograph on London 'witches' as a contemporary example), in so-called traditional societies almost all the 'salient, socially significant and memorable' claims to truth are made in the context of 'traditional' interaction (1990:113).

For a 'strong' reading of tradition incorporated in a developed analysis of contemporary global society it is to Anthony Giddens we must turn. Giddens sees tradition as playing a central role in pre-modern societies both in respect of its role in identity formation but, more significantly for us, in its relation to authority. In respect of the former, Giddens argues that tradition is one of four 'localised contexts of trust' which maintains ontological security in pre-modern societies. ${ }^{7}$ In respect of the latter, Giddens, like Boyer, sees tradition playing a central role in structuring social activity in a relatively fixed social landscape through ritualised affirmation of authority (1994:6). (It is also important to appreciate the connection, via trust, between the identity and institutional functions of tradition.)

Contemporary global society, Giddens continues, is 'post-traditional'. This is not because tradition disappears but rather changes its status. Tradition now exists alongside other forms of social practice and hence becomes a choice - no longer simply the way things are done. Further, and more importantly, due to the increasingly reflexive nature of social institutions, tradition has now to explain itself: it has to give reasons, become open to interrogation and discourse (1994:5). The demise of tradition is thus directly linked to its purging from institutional practice as modern society has become more reflexive: post-fordist industry and political democracy are examples here. 'Detraditionalisation' is thus on the rise as all aspects of contemporary social life become colonised by reflexive social practice (1994:6). This suggests that, like Boyer, Giddens sees 'real tradition' as involving more than long-established practice but also a particular form of validation involving key institutions.

This stated, Giddens acknowledges that the influence of tradition remains strong. This is partly because in the earlier phases of the development of modern societies (which he terms 'simple modernisation' and distinguishes from 'complex modernisation') a refocusing or re-invention of tradition played a major role in consolidating the social order. Nationalism is an obvious example, but no less important were gender and sexual practices. Even science became a sort of tradition in that its universal authority was unquestioningly accepted for some time. Given the uneven nature of development globally it seems reasonable to assume that some sectors would still be under- 
going mostly 'simple' rather than 'reflexive' modernisation, although the impact of systems of instant communication (as well as different historical conditions such as colonialism) will render this a different process from the European experience. Lastly, but importantly, Giddens argues that we can understand the recent rise of fundamentalism as the defence of tradition in the traditional way - but in a context where that mode of defence has been called into question. In a globalising, culturally cosmopolitan, information technology-driven society the ritual assertion of truth amounts to a refusal of dialogue which runs against the evident plurality of choice, but more significantly, the increasing reflexivity of social life (1994:6).

Thus Giddens joins Boyer against Shils in relating tradition to a specific form of justification - the ritual assertion of its truth by authority. Hence while all societies can be said to share some sort of tradition insofar as this means a long established social practice therefore assigned normative value, not all societies operate in 'traditionalist' ways. That the 'strong' reading of tradition is more convincing is suggested by the fact that in traditional societies, tradition did change - although certainly not the kind of change contemporaries are used to. What this suggests is that it's not simply the persistence of practice which lends tradition its meaning, but the particular mode of its validation. 'Traditionalism' as David Apter puts it, or the traditionalist defence of tradition, is thus equally important and it is this additional element which strong readings also incorporate (1968:115).

\section{Conclusion}

He has two antagonists: the first presses him from behind, from the origin. The second blocks the road ahead. He gives battle to both. To be sure the first supports him in his fight with the second, for he wants to push him forward, and in the same way the second supports him in his fight with the first, since he drives him back. But it is only theoretically so. For it is not only the two antagonists who are there but he himself as well, and who really knows his intentions. His dream though, is that in an unguarded moment ... he will jump out of the fighting line and be promoted, on account of his experience in fighting, to the position of umpire over his antagonists in this fight with each other.

Franz Kafka

The question of the rehabilitation of tradition in the context of the current Stimmung has thus led to an ambiguous conclusion. On the one 
hand, Gadamer's retrieval of tradition as the source of our prejudices necessary to the hermeneutics of understanding undermines reason's exclusive claims to truth-redemption. Yet this does not aid the English traditionalists Burke and Oakeshott as, on the other hand, Gadamer simultaneously undermines tradition's claims to primacy in truthredemption. Rather, he transcends the tradition-reason opposition, incorporating both as partners in meaning-construction. Sociologically, tradition's redemption is equally ambiguous. On the one hand, tradition - understood in the weak sense of a long established practice therefore assigned normative value - is affirmed as present in all societies, even the most developed. On the other, traditionalism - the defence of tradition in the traditional way - is no longer the defining feature of contemporary institutional practice. Understood in this strong sense, tradition is connected with particular social forms of authority which can be empirically measured. If Giddens is right, then contemporary global society is increasingly a post-traditional one.

This ambiguity has significant consequences for the association of tradition with ethnic and nationalist discourses. It sets up extreme alternatives: on the one hand, in a context where tradition's a priori claim to truth is undermined and it is increasingly challenged to explain itself, fundamentalism becomes a possibility. This can be seen as a failure of the Gadamerian hermeneutical circle, where difference leads not to mutual understanding but increasing hostility and violence. On the other hand, as traditionalism becomes increasingly seen as outdated, there is the danger that the normative validation of the past, and with it ethnic difference, becomes rejected altogether. Not only an infringement of human rights, ${ }^{8}$ the long-term consequences of this repression can be equally devastating. It seems then that ethnicity and nationalism must appropriate tradition in a way which both affirms it yet keeps it open to otherness - a tension not easily managed but unavoidable in the 'developing' African context. 


\section{NOTES}

1. The reply of a school student when asked 'How important is the History of the Zulu people to you?'. From a recent case-study of the ethnic identity and political affiliation of Zulu-speaking school-children at a Pietermaritzburg school (Wedekind et al. 1993).

2. In Imagined Communities he writes:

Because there is no Originator, the nation's biography cannot be written evangelically, 'down time', through a long procreative chain of begettings. The only alternative is to fashion it 'up time' - towards Peking Man, Java Man, King Arthur, wherever the lamp of archaeology casts its fitful gleam. This fashioning, however, is marked by deaths, which, in a curious inversion of conventional genealogy, starts from an original present. World War II begets World War I; out of Sedan comes Austerlitz; the ancestor of the Warsaw Uprising is the state of Israel. (1991:205)

3. See John Lonsdale's 'The Moral Economy of the Mau Mau', in B. Berman and J. Lonsdale, 1992, pp.265-504.

4. The classic statement of this problem in South Africa was by Albert Luthuli:

We were thoroughly aware of the meeting of cultures, African and European, and of the disorganisation of both ... as a result. We do not have the desire of the Nationalists that we should return to the primitive. But we did have an intense wish to preserve what is valuable in our heritage while discarding the inappropriate and outmoded ... Our task seemed to consist of relating the past coherently to the present and the future. (1962:35)

For fuller treatment of this dynamic see Shula Marks, The Ambiguities of Dependence, 1986; and Basil Davidson, The Black Man's Burden, 1992.

5. A Heideggerian term, Stimmung refers to an amorphous, protean, and shifting mood which nevertheless exerts a powerful influence on the ways in which we think, act and experience (Bernstein 1991:11).

6. An example here is Gadamer's claim against Habermas that the acceptance of authority is not always a question of coercion or reflexive insight into the legitimacy of authority, but rather depends upon 'dogmatic recognition'. This is the realisation that as one can find no independent grounds for reflecting upon the legitimacy or otherwise of authority, one has no basis to criticise 'knowledgeably', and thus that authority must have superior insight than oneself.

7. Important in this regard, is a distinct mode of structuring temporality which Levi-Strauss terms 'reversible time'. What this means is that tradition's 'orientation to the past' is not backward looking in the way a modern person with a linear conception of time would understand it. Neither the past nor future is a discrete phenomenon separable from the present in the way we might believe. An example here are the philosophers in pre-Ch'in China, who conceived of the intersection of the past and present as a mobile relation, where history runs 'laterally' rather than 'backwards' or 'forwards' (1984:201). As Giddens puts it, 'past time is incorporated into present practices such that the horizon of the future curves back to intersect with what went before' (1990:105). Tradition contributes to ontological security by sustaining trust in the continuity of past, present and future, and connects such trust to routinised social practices (1991:148).

8. See Taylor (1992). 


\section{REFERENCES}

Anderson, B. 1991. Imagined Communities. London \& New York: Verso. Apter, D.E. 1965. The Politics of Modernization. Chicago: University of Chicago Press. 1968. Some Conceptual Approaches to the Study of Modernisation. New Jersey: Prentice-Hall.

Arendt, H. 1961. Between Past and Future: six exercises in political thought. London: Faber \& Faber.

Bauman, Z. 1992. Intimations of Postmodernity. New York: Routledge.

Berman, B. \& Lonsdale, J. 1992. Unhappy Valley: Conflict in Kenya and Africa. London: James Currey.

Bernstein, R.J. 1991. The New Constellation. Cambridge: Polity.

Boyer, P. 1990. Tradition as Truth and Communication: A cognitive description of traditional discourse. Cambridge: Cambridge University Press.

Butler, M. (ed.). 1984. Burke, Paine, Godwin and the Revolution Controversy. Cambridge: Cambridge University Press.

Davidson, B. 1992. The Black Man's Burden: Africa and the Curse of the Nation-State. New York: Time Books.

Gadamer, H.G. 1975. Truth and Method. London: Sheed \& Ward.

Gellner, E. 1992. Reason and Culture. London: Blackwell.

Giddens, A. 1984. The Constitution of Society. Cambridge: Polity. 1990. The Consequences of Modernity. Cambridge: Polity. 1991. Modernity and Self-Identity: Self and Society in the Late Modern Age. Cambridge: Polity. 1994. Beyond Left and Right: The Future of Radical Politics. Cambridge: Polity.

Habermas, J. 1985. The Philosophical Discourse of Modernity. Cambridge: Polity.

Hekman, S.J. 1986. Hermeneutics and the Sociology of Knowledge. Notre Dame, Indiana: University of Notre Dame Press.

Heller, A. \& Feyer, F. 1988. The Postmodern Political Condition. Cambridge: Polity.

Hobsbawm, E. \& Ranger, T. 1983. The Invention of Tradition. Cambridge: Cambridge University Press.

How, A.R. 1980. 'Dialogue as Productive Limitation in Social Theory: The Habermas-Gadamer Debate', Journal of the British Society for Phenomenology, vol. 11, no. 2, pp.131-143.

Luthuli, A. 1962. Let My People Go. London: Macmillan.

Marks, S. 1986. The Ambiguities of Dependence. Cambridge: Cambridge University Press.

Mendelson, J. 1979. 'The Habermas-Gadamer Debate', New German Critique, no. 18 , pp.44-74. 
Oakeshott, M. 1962. Rationalism in Politics and Other Essays. London:

Methuen.

Outhwaite, W. 1975. Understanding Social Life. London: George Allen \& Unwin.

Palmer, R.E. 1969. Hermeneutics: Interpretation Theory in Schleiermacher, Dilthey, Heidegger and Gadamer. Evanston, Ill.: Northwestern University Press.

Shils, E. 1981. Tradition. London \& Boston: Faber \& Faber.

Taylor, C. 1989. Sources of the Self: The Making of Modern Identity. Cambridge: Cambridge University Press. 1992. Multiculturalism and 'The Politics of Recognition'.

Princeton: Princeton University Press.

Thompson, J.B. 1990. Ideology and Modern Culture. Great Cambridge:

Polity.

Warnke, G. 1987. Gadamer: Hermeneutics, Tradition and Reason.

Stanford: Stanford University Press.

Wedekind, V., Shange S., \& Piper, L. 1993. 'Ethnicity, Identity and

Schooling: reflections on a case-study in Pietermaritzburg', in S.

Pendlebury, L. Hudson, Y. Shalem, and D. Bensusan (eds), Kenton at

Broederstroom 1992: Conference Proceedings. University of the

Witwatersrand: Johannesburg, pp.21-33. 